\title{
WAYS TO INCREASE THE SUSTAINABILITY \\ OF THE AGRICULTURAL SECTOR OF THE ECONOMY
}

G.I. Sharyi, D. in Economics, Professor, Department of Highways, Geodesy, Land Management and Rural Buildings

S.V. Nesterenko, Candidate of Technical Sciences (Ph. D.), Associate Professor of the Department of Highways, Geodesy, Land Management and Rural Buildings

V.V. Shchepak, Candidate of Technical Sciences (Ph. D.), Associate Professor of the Department of Highways, Geodesy, Land Management and Rural Buildings

National university "Yuri Kondratyuk Poltava polytechnic»

E-mail: NesterenkoS2208@gmail.com

\section{ABSTRACT}

The factors that cause the destruction of natural complexes, degradation of agricultural lands are considered. It was revealed that the crisis phenomena of state institutions affected the low resistance of agricultural production to the negative effects of natural and climatic nature. The need to consider the urgent problem of drought, which affects the deterioration of natural conditions, and, consequently, to reduce yields. This requires a change in the system of agricultural machinery in the direction of development of the reclamation complex for irrigation of agricultural land, especially on lands of intensive agriculture.

It was noted that the neoliberal regulatory policy of the state and the liberalization of agrarian relations have stopped the development of intensive reclaimed agriculture. It was found that over the past 30 years, land with reclamation systems has become the private property of individuals. The lack of responsibility for the proper use of irrigation systems has led to a rupture of technological integrity, to the destruction of their functional properties.

There is a need to form a system of efficient and rational use of agricultural land, taking into account the conditions of drought, which will explore the peculiarities of the interaction of system components and form a balance between efficiency (profitability) and rational sustainable use of agricultural land. 
Based on the modeling, the factors influencing the organization of efficient use of agricultural lands are determined. A graph-model of the system of organization of efficient and rational use of agricultural lands has been formed. A structural and logical model of overcoming drought on agricultural lands based on the development of the reclamation complex is proposed.

As a result of research, it was concluded that to overcome the impact of drought on agricultural production is possible provided the development of reclamation complex for irrigation of agricultural land and the formation of effective state mechanisms of regulatory economic policy in agricultural land use.

Keywords: agricultural land, drought, land reclamation, model, system, rational use of land, sustainability of agricultural production.

\section{INTRODUCTION}

The economic system in Ukraine is in a state of deep crisis, caused by the institutional trap of state corruption, half-hearted state policy in the field of ecology and land management, neoliberal economic and agricultural policy. The unresolved problems of a constantly degrading environment require immediate decisive steps towards the preservation and restoration of the environment and nature.

Scientific theories in the field of land protection and conservation must be constantly improved as effective tools to correct the situation and respond to the challenges that have arisen in land use over the past half century. The environment and natural ecosystems degrade under the pressure of industrialization, urbanization, climatic factors, which leads to the destruction of natural complexes, degradation of agricultural land. We are especially acutely irrational in the use of nature in Ukraine.

\section{FORMULATION OF THE PROBLEM}

Rational use of land resources and directly agricultural land is the basis of efficient agricultural production. Deterioration of natural economic conditions has shown that the crisis of state institutions has affected the low resilience of agricultural production to the negative effects of natural and climatic nature. 
The aim is to study the factors that negatively affect the condition of agricultural lands, in particular, droughts and to suggest ways to overcome it on agricultural lands.

\section{ANALYSIS OF RECENT RESEARCH AND PUBLICATIONS}

In Ukraine, 42,726.4 thousand hectares or $70.8 \%$ are agricultural lands, of which 41,507.9 thousand hectares $(68.8 \%)$ belong to agricultural lands, in particular, to arable land - 32,541.3 thousand hectares ( 53.9\%), hayfields - 2406.4 thousand hectares (4.0\%); pastures - 5434.1 thousand hectares (9.0\%). In Ukraine, more than 92 percent of the territory is involved for economic use. The level of plowing of the territory is extremely high and is over 54 percent (in developed European countries does not exceed 35 percent) [1].

In the works of Poprozman N.V., Korobska A.O. special attention is paid to the fact that due to the high level of agricultural development of the land fund there is a spread of land degradation processes [2]. O. Budziak emphasizes the need for the introduction of innovative methods of reclamation of disturbed lands [3].

According to statistics, there are more than 1.1 million hectares of degraded, unproductive and man-made contaminated land in Ukraine, 143.4 thousand hectares of disturbed land in need of reclamation, and 315.6 thousand hectares of lowproductivity land in need of conservation. improvement [4].

Agricultural scientists pay attention to the deterioration of natural conditions, which is caused by drought, which reduces yields. Such conditions require the introduction of reclamation measures. At the same time, there is inefficient use of a significant amount of distributed land, which is leased or not used for its intended purpose at all. The efficiency of agricultural activity and the agricultural sector in general depends on the quality of land resources $[5,6]$. But research and proposals in the field of drought management are not enough.

\section{RESULTS AND DISCUSSION}

Ukraine belongs to the regions with developed agriculture. But today the agriculture of Ukraine depends not only on the level of management, but also on, often unfavorable, natural and climatic conditions. The issues of sufficient moisture 
supply of agricultural crops, which during the growing season in large areas of Ukraine is not possible without the effective functioning of irrigation, rational use of reclaimed land, organic farming and drought-resistant drought-resistant crop rotations, have become especially acute.

Since 2011, the temperature of the warm period of the year and the daytime temperature has been growing rapidly in Ukraine, the growth of which is more intensive than the growth of temperatures in the winter and night periods (Fig. 1). This leads to disruption of the physical processes of condensation of water vapor at night, creates conditions for the predominance of evaporation over infiltration supply, reduces the level of groundwater and reduces moisture reserves in the soil. Low water has especially intensified in Ukraine since 2013.

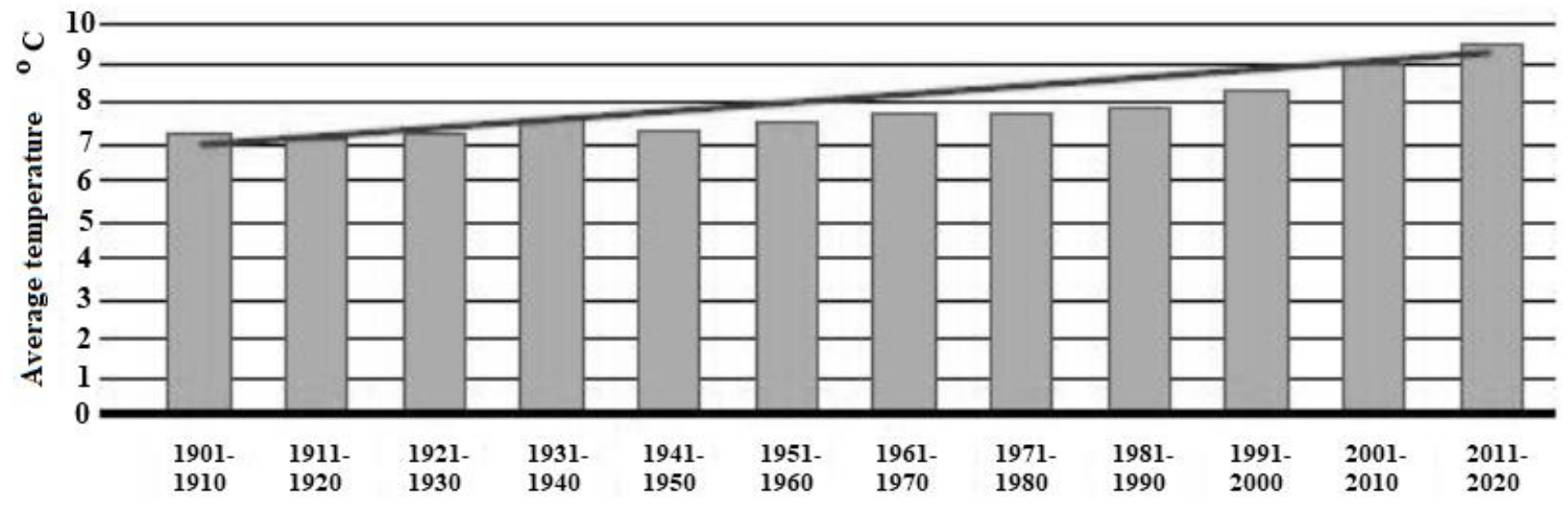

Fig. 1. Dynamics of change of average annual air temperature in Ukraine [7]

The temperature of the warm period in Polissya reached the temperatures typical for the Forest-Steppe of Ukraine. Since 1991, each subsequent decade has been warmer than the previous one: $1991-2000$ - by $0.5^{\circ} \mathrm{C}, 2001-2010$ - by $1.2^{\circ} \mathrm{C}, 2011-$ 2019 - by $1.7^{\circ} \mathrm{C}$ (Fig. 2).

The amount of precipitation during the warm period (April - October) in the steppe regions is about $90 \%$, forest-steppe $-80 \%$, Polissya $-110 \%$ of the norm, in many areas of the southern regions - only $50-70 \%$ of the norm. During the warm period, with the predominance of the deficit of precipitation, a large amount of precipitation of inefficient heavy rains was recorded, when the daily maximum of precipitation reached or exceeded the monthly norm [8]. 


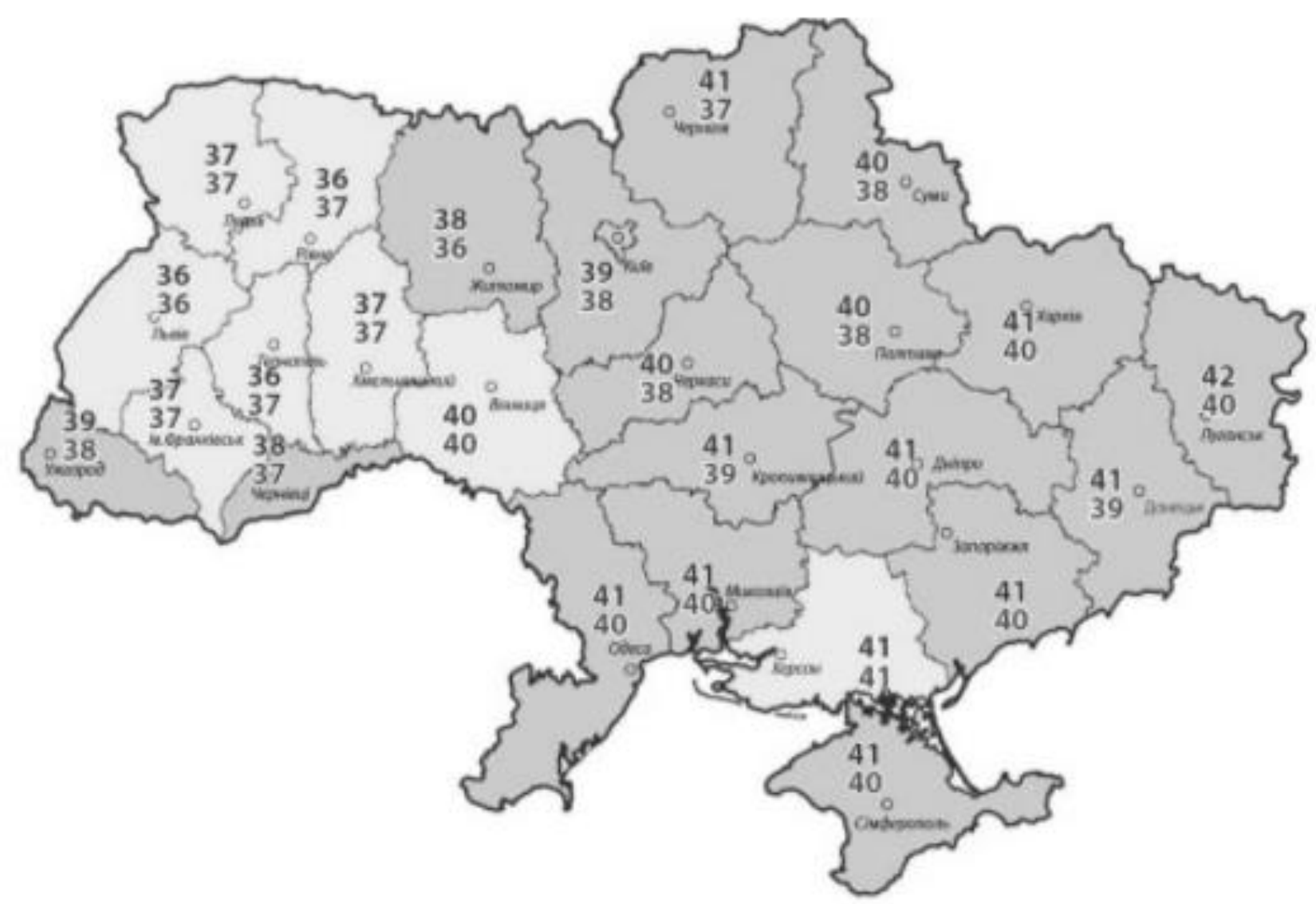

Fig. 2. Cartogram of the highest air temperature (absolute maximum), ${ }^{\circ} \mathrm{C}$ : upper figures - for the period 1961-2005, lower - for the period 2006-2019. [7]

Maintaining the trend of increasing temperature and decreasing precipitation leads to an increase in the depth of groundwater, which in Polissya is now located at depths that were characteristic of the Forest-Steppe (2.0 - $2.5 \mathrm{~m}$ and more). In turn, in the Forest-Steppe groundwater is now deposited at depths that are characteristic of the Steppe zone and the Dry Steppe zone (3.0 - $3.5 \mathrm{~m}$ and more). Groundwater levels in Ukraine have been set at levels where water is less accessible or even inaccessible to most plants.

The drought hit a number of agricultural regions of Ukraine in 2020, threatening the existence of not only agricultural enterprises, farms and the possibility of farming.

This requires a change in the system of agricultural machinery in the direction of development of the reclamation complex for irrigation of agricultural land, especially on lands of intensive agriculture, in particular beet, vegetable and fodder production; formation of a more drought-resistant system of agriculture. 
Despite the change of natural and climatic conditions towards dry periods, from year to year in Ukraine agricultural producers continue to sow only moistureintensive 'top' crops: corn, sunflower and soybeans. Having brought the wedge of arable crops in the structure of crops to $80 \%$, by agricultural consumption of intensive farming, agricultural producers continue to dehydrate forest-steppes to a state of dry steppe.

Liberal agrarian and land legal relations on agricultural lands do not have legally binding norms on sustainable development and fertility support. Agricultural producers, especially small ones, are not engaged in reclamation work or radical land improvement. In Ukraine, cultural and technical works and contour and reclamation organization of the territory have been lost.

In recent years, the passivity of the Ministry of Agriculture in the structure of central executive bodies, neoliberal regulatory policy and liberalization of agrarian relations have often significantly reduced the economic stability of the agricultural sector of Ukraine. Land distribution and the lack of effective measures in the field of reclamation have stopped the development of intensive reclamation agriculture. Thus, if in Ukraine during 1990-2020 there were no significant fluctuations in the area of drained land, the area of irrigated land decreased by 10 times [1].

For example, in 1990, the water management and reclamation complex of Poltava region covered 87,996 thousand hectares of reclaimed land, including 50,804 - irrigated and 37,192 - drained, or 4\% of agricultural land in the region. If in Ukraine the reclamation of lands in comparison with the world level in 1990 was in its infancy, now the state of land reclamation in general indicates the absence of reclamation works.

Irrigation systems of Poltava region have not been working for almost 25 years (40.3 thousand hectares were irrigated in 1990, and 1.1 thousand hectares in 2000, no watering since 2007), 4 thousand hectares were irrigated in 2020, (drip irrigation 300 hectares). 
In Ukraine, in addition to natural and climatic factors, the main cause of drought and lack of irrigation, in addition to climatic factors, is the legislative uncertainty of land relations and the temporary nature of agricultural land use.

During the period 1990-2020, lands with reclamation systems became the private property of individuals. As of January 1, 2020, irrigation lands of Poltava region with an internal network of irrigation systems are used by 717 land users and landowners, including 53 agricultural enterprises, 664 individuals (12 of them are farms). The rupture of technological integrity and the lack of responsibility for the proper use of irrigation systems, which in many cases have been left without an owner, have led to the destruction, looting and loss of functional properties of the systems.

For Ukraine, 2020 is marked by the adoption of the Law «On Amendments to Certain Legislative Acts of Ukraine on the Circulation of Agricultural Land» and the termination of the moratorium on the sale of agricultural land [9]. Many manipulations to delay the purchase and sale of land for several years have partially achieved the goal, and most restrictions on the circulation of agricultural land remain. The principles of transparency, economic and legal equality of economic entities are ignored due to the restriction and postponement of the possibility of purchasing agricultural land for legal entities - tenants, who have been cultivating land for years, ensuring targeted land use, paying land payments and maintaining natural fertility. and especially irrigation.

In no way did the adoption of the 'land market' affect the peasants, whose interests the politicians 'defended'. But, talking to representatives of agricultural companies (heads of land departments), we can draw the following conclusions:

- granting the right to buy land only to individuals, will deepen the shadowing of land relations and put the land in the economic underground;

- agricultural companies will train proxies to buy land plots. At the same time, farms, medium-sized enterprises and large agricultural companies will not lose the opportunity to buy land in which funds have been invested for decades, especially on reclaimed land; 
- landowners who have decided to sell land, artificially inflate the price;

- owners of land plots (shares) are afraid to enter into lease agreements and extend the term of agreements, including irrigation, which requires explanatory work, because the lease does not limit the transfer of ownership.

At the time of adoption of the bill 'On Amendments to the Land Code of Ukraine and other legislative acts to improve the management and deregulation system in the field of land relations' [214]. The Committee of the Supreme Council of Ukraine on Agrarian and Land Policy prepared the draft for the second reading on October 7, 2020, and its adoption will logically complete part of the preparatory work before the introduction of full-fledged circulation of agricultural land.

The bill is designed to regulate and ensure:

- decentralization of land management and empowerment of communities. Communities need to pay attention to the full range of land users that need to fill the local budget. Most small farms use shady plots without registering leases and do not declare income. For example, in Poltava region, without lease agreements, more than 40 thousand land plots are formed, which were formed from shares, which is 170 thousand hectares of arable land [11];

- reforming the powers of state executive bodies in the field of land relations of the State Geocadastre, which becomes a public service, the main task of which will be the maintenance of land cadastre and the creation and integration of state geographic information systems [12]. The Land Management Center is transferred to the community level [13];

- restrictions on the use of lands, objects and territories of the nature reserve fund and lands of historical and cultural purpose;

- elimination of schemes and primary sources of bribery and corruption in land relations, which are associated with repeated duplication of procedures for inspection, examination and approval of documentation on land management, administration and redistribution of land;

- abolition of restrictions on access to land resources of citizens and businesses, in particular, approvals of the Cabinet of Ministers and the Parliament of Ukraine; 
- providing land management documentation in Ukraine with the status of public, open and publicly available data [14];

- simplification of land valuation;

- establishment of a certain procedure for the exercise of the preemptive right to acquire land;

- the possibility of transferring the right of emphyteusis for rent;

- granting the right to the founders of farms and their heirs, who received land plots for farming on the terms of permanent use and lease, to acquire property.

Legal initiatives should form the powers of local self-government in the field of land relations. Shading of violations within communities should stop, as the budget and development of the community depend on the economic behavior of community land users, the responsibility of residents and the results of transparency of land relations and completeness of land payments.

In 2025, unclaimed shares will also become the property of communities. The official order will strengthen the responsibility of local self-government in making decisions on the conditions of transfer of land for rent or ownership free of charge.

These legislative initiatives require the inclusion of land in the state cadastral register. We have many examples when land management documentation for owners of land plots (shares) is made at the expense of tenants, but communities need to be involved in the work, especially with regard to communal lands.

Most land users, including farmers, share the principles of large agricultural holdings and support landlords in inheriting or entering land in state registers. If such principles are followed by all land users without exception, communities will develop and villages will receive a new status, because there will be a development budget in each village, and land relations will become transparent and come out of the economic underground. Despite the imperfection of lease relations, agricultural enterprises, including farms, seek to organize profitable production, not always paying attention to the condition of agricultural land [2]. There is a need to form a system of organization of efficient and rational use of agricultural land in production, which will explore the peculiarities of the interaction of system components and form 
ways to ensure a balance between efficiency (profitability) of production and rational sustainable use of agricultural land.

The organization of efficient use of agricultural land in production is characterized by the influence of various environmental factors. To ensure effective management of agricultural production, there is a need to study the factors that have a significant impact on the condition of agricultural land.

Modeling was used to determine the main factors influencing the organization of efficient use of agricultural land.

When creating the model, a set of logical relations was used. By definition, the model is abstract. It identifies the most significant factors, determines the patterns of functioning of the system of efficient use of agricultural land and abstracts from other factors that have little impact. It is assumed that all factors that are not taken into account in the model have a negligible impact on the system.

When forming the model, all the relationships of the system of organization of efficient use of agricultural land can be quantified, which allows to obtain objective data on the state of functioning of this system.

Interpretation of the simulation results aims to move from the information obtained from the study of the model to the description of the components and relationships of the system of organization of efficient and rational use of agricultural land.

Based on the analysis of modeling results, decisions are made about the conditions in which the system will function most efficiently and the land will be used rationally.

The model of the system of organization of efficient use of agricultural lands is considered as a set of consolidated components, fundamentally necessary for the existence and functioning of the studied system. The unity of the elements of the system, the connections and interactions between them form the integrity of the system, and the components - the structure.

As a result of the analysis, the components were identified and the interrelationships of the system of organization of rational use of agricultural lands 
were determined. The consolidated components of this system are four components: agricultural land, natural factors, territory and agricultural enterprises. There are relationships between the components.

Based on this approach, a graph model is formed (Fig. 3). The presented model has edges (connections) and vertices (components), which are combined into a single system (S). Each component of the system corresponds to a certain vertex of the graph-model.

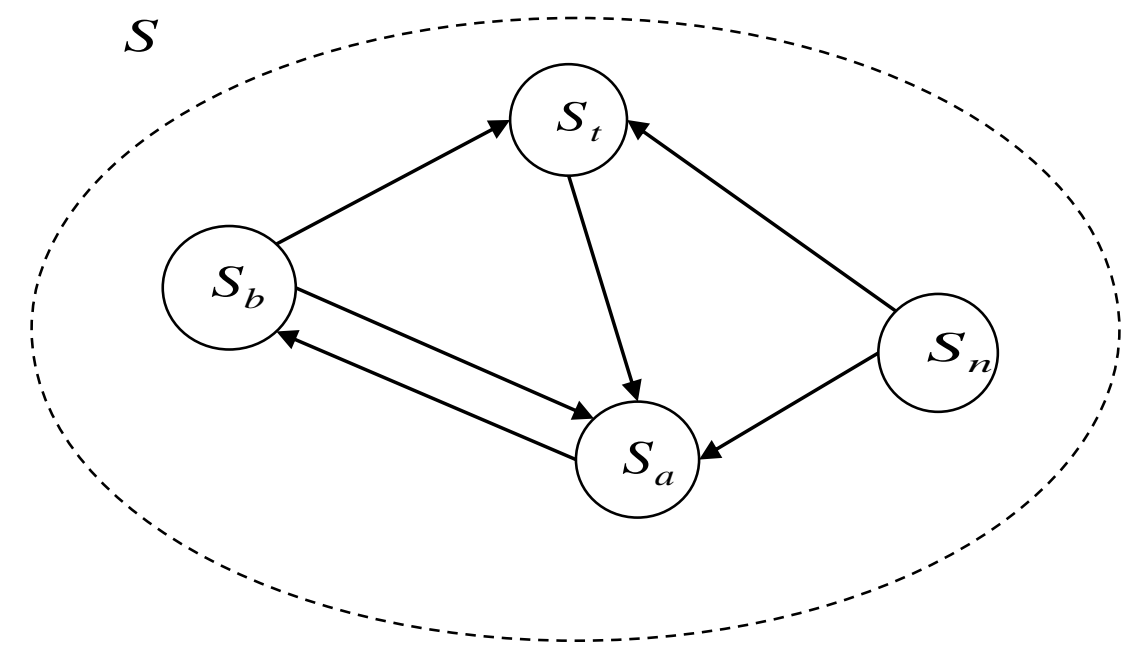

Fig. 3. Graph-model of the system of organization of efficient and rational use of agricultural lands

Agricultural enterprises correspond to the vertex $S_{b}$, territories $-S_{t}$, agricultural lands $-S_{a}$, natural factors $-S_{n}$. The edges of the graph model $\left(S_{b}-S_{a}\right),\left(S_{a}-S_{b}\right),\left(S_{b}-\right.$ $\left.S_{t}\right),\left(S_{t}-S_{a}\right),\left(S_{t}-S_{n}\right),\left(S_{n}-S_{a}\right)$ characterize the relationship between the components of the system of organization of efficient use of agricultural lands (Fig. 4). It is proposed to describe the graph-model of the system of organization of efficient and rational use of agricultural lands on the basis of structural-functional approach [13]. A study of the system was conducted and determined:

- the primary element of the system $\left(S_{i} \in S\right.$ ), $i=b, t, n, a$;

- compiled a list of components based on the method of structural decomposition; 
- determined the connections between the components in the system;

- formed influence on process systems $(Y o)$;

- defined the mechanism of realization of the purposes of system:

$$
(F \times Y o \times G \rightarrow E o),
$$

- determined the mechanism of system functioning:

$$
(Y o \rightarrow E o)
$$

The result is a general model of the system of organization of efficient and rational use of agricultural land. The description of the system (S) of the graph model has the form:

$$
S=\left\langle Y_{o}, E_{o}, F, G, R\right\rangle
$$

where $Y o$ - the cost of resources of the system of organization of efficient use of agricultural land;

Eo - efficiency of the system of organization of efficient use of agricultural lands;

$F$ - macro system functions;

$G$ - system structure;

$R$ - relation, emergence.

Emergence characterizes the integrity of a system, which arises from the combination of components into a single system.

The macro functions of the system are quantitative characteristics of the system and depend on the cost of resources it consumes. The choice of macro function ensures the achievement of the required economic efficiency of the system. It is related to solving the problems facing the system. Only with certain resources $\left(Y_{o}\right)$ it is possible to ensure the efficiency $\left(E_{o}\right)$ of the system.

The mathematical expression of the macrofunction has the form:

$$
F: Y o \rightarrow E o,
$$

Achieving the main goal of the system is possible with the implementation of the macrofunction $(F)$, which must meet a certain structure of the system $(G)$ and its integrity $(\mathrm{R})$ :

$$
R: F \rightarrow G
$$


Emergence (R) specifies the correspondence between the macrofunction of the system (F) and the structure $(\mathrm{G})$ that it implements. Emergence $(\mathrm{R})$ changes each time the correspondence between macrofunction and structure is breaks down.

Dependence is defined as follows:

$G=\left\langle\left\{\left(S_{b}, S_{t}, S_{a}, S_{n}\right\}\left(S_{b}-S_{a}\right),\left(S_{a}-S_{b}\right),\left(S_{b}-S_{t}\right),\left(S_{t}-S_{a}\right),\left(S_{t}-S_{n}\right),\left(S_{n}-S_{a}\right)\right\rangle\right.$,

де $\left\{S_{b}, S_{t}, S_{a}, S_{n}\right\}$ - vertices of the graph-model;

$b, t, a, n$-indices characterizing the components of the system, respectively, agricultural enterprises, territories, agricultural lands, natural factors;

$\left(S_{b}-S_{a}\right),\left(S_{a}-S_{b}\right),\left(S_{b}-S_{t}\right),\left(S_{t}-S_{a}\right),\left(S_{t}-S_{n}\right),\left(S_{n}-S_{a}\right)$ - connections between the vertices of the graph-model. The components of the graph-model are represented by the functions:

$$
\begin{aligned}
& f_{1}: S_{b} \rightarrow\left\{B_{1}, B_{2}, B_{3}\right\}, \\
& f_{2}: S_{t} \rightarrow\left\{T_{1}, T_{2}, T_{3}\right\}, \\
& f_{3}: S_{a} \rightarrow\left\{A_{1}, A_{2}, A_{3}, A_{4}, A_{5}\right\}, \\
& f_{4}: S_{n} \rightarrow\left\{N_{1}, N_{2}, N_{3}\right\}, \\
& f_{5}:\left(S_{b}-S_{a}\right) \rightarrow\left\{B A_{1}, B A_{2}\right\}, \\
& f_{6}:\left(S_{a}-S_{b}\right) \rightarrow\left\{A B_{1}\right\}, \\
& f_{7}:\left(S_{b}-S_{t}\right) \rightarrow\left\{B T_{1}, B T_{2}, B T_{3}\right\}, \\
& f_{8}:\left(S_{t}-S_{a}\right) \rightarrow\left\{T A_{1}, T A_{2}\right\}, \\
& f_{9}:\left(S_{n}-S_{a}\right) \rightarrow\left\{N A_{1}, N A_{2}, N A_{3}\right\},
\end{aligned}
$$

The first four functions characterize the components of the system, the other functions - the connections between them.

Agricultural enterprises are characterized by production infrastructure $\left(B_{1}\right)$, material and technical resources $\left(B_{2}\right)$, financial resources $\left(B_{3}\right)$.

The area where agricultural production is organized is characterized by area $\left(T_{1}\right)$, relief $\left(T_{2}\right)$, transport infrastructure $\left(T_{3}\right)$.

Agricultural lands are characterized by soil quality $\left(A_{1}\right)$, ecological stability $\left(A_{2}\right)$, soil degradation $\left(A_{3}, A_{4}\right)$, soil moisture level during the growing season $\left(A_{5}\right)$, which forms the aspect of sustainable rational use. 
Natural factors that affect agricultural land are characterized by annual precipitation $\left(N_{1}\right)$, air temperature $\left(N_{2}\right)$, dry winds $\left(N_{3}\right)$.

The functions that characterize the relationships between the components of a system have certain characteristics. Between agricultural enterprises and agricultural lands are production volumes $\left(B A_{1}\right)$, production costs $\left(B A_{2}\right)$, gross marketable products $\left(A B_{l}\right)$; between agricultural enterprises and the territory - are the transport costs $\left(B T_{1}\right)$, travel time $\left(B T_{2}\right)$, costs of organization of the territory $\left(B T_{3}\right)$; between the territory and agricultural lands - is the distance $\left(T A_{1}\right)$, planning characteristics $\left(T A_{2}\right)$; between natural factors and agricultural lands - is the amount of precipitation $\left(N A_{1}\right)$, the number of dry winds $\left(N A_{2}\right)$, temperature regime $\left(N A_{3}\right)$.

The interaction of components, as a whole system, ensures their dynamic development. The proposed model of the system of organization of efficient and rational use of agricultural lands shows the interdependence of its components and describes the parameters of their interaction.

The use of modeling allowed to determine the most important relationships between the components of the system of organization of efficient use of agricultural land and to characterize the relationships between the parameters of these components.

The authors single out natural factors that have a significant impact on the condition of agricultural land, in particular in drought conditions. The balance of the system can be maintained in the conditions of Poltava region only due to crop rotations and irrigation. Agricultural enterprises seek to implement measures to combat such conditions.

Agricultural companies in Poltava region, despite the imperfection of lease relations and economic risks, are renewing irrigation systems [15].

To provide irrigation, a network of water storage structures is needed: reservoirs and ponds. On the territory of Poltava region there are 2679 pieces. ponds and 69 pcs. reservoirs with appropriate hydraulic structures - earth dams, retaining, culverts and drainage structures of various types and designs. 
Analysis of the water management situation on water bodies, which has developed, for example, in Poltava region, shows that the care of hydraulic structures in districts and cities is unsatisfactory, repairs are not carried out in time, so some hydraulic structures of reservoirs are brought to unsatisfactory condition. To date, up to 500 ponds in the region (almost one-fifth) have dried up completely, and most have dropped by almost half. Even if farmers want to irrigate land, the lack of water sources, without reconstruction and construction of water storage facilities makes irrigation impossible. Therefore, it is time for legal regulation of production, lease, concession of hydraulic complexes by agricultural companies.

Countries around the world increase the share of reclaimed land to 80 percent, which indicates high stability of crop productivity, food security and resilience of agricultural production to adverse climatic factors.

In the arrays of agricultural enterprises of Ukraine there are tens of thousands of hectares of problematic arable land with existing drainage systems. The presence of drainages excludes full-fledged autumn-winter water accumulation, accumulation of moisture in the 2-meter layer and the positive impact of groundwater on fertility and without the organization of irrigation on such lands, effective agriculture is simply impossible.

The authors proposed a structural and logical model of overcoming drought on agricultural lands (Fig. 4).

The developed model envisages reclamation measures in the fight against drought. In particular, the construction of hydraulic structures.

It is necessary to change the policy of lease relations on reclaimed lands, in comparison with rainfed lands for the purpose of guaranteed and stable spatial basis, through long-term lease, through land purchase, by changing contractual conditions taking into account inseparable reclamation improvements and normative profitability of irrigated lands. Contractual terms with landowners are confidential and personal, but require an effective regulatory policy to consolidate reclaimed land and special use and mandatory irrigation. The legislator has set the minimum lease term at 10 years for irrigation, which is only 3 years more than undeclared land. 
Legal protection of tenants who make inseparable improvements have organized irrigation, added organic farming, contour-ameliorative organization of the territory, requires longer lease terms and the possibility of buying land. Land relations on reclaimed lands and lands of organic farming require state regulation and state incentives to support tenants who can and want to use arable land under irrigation and on the basis of organic farming.

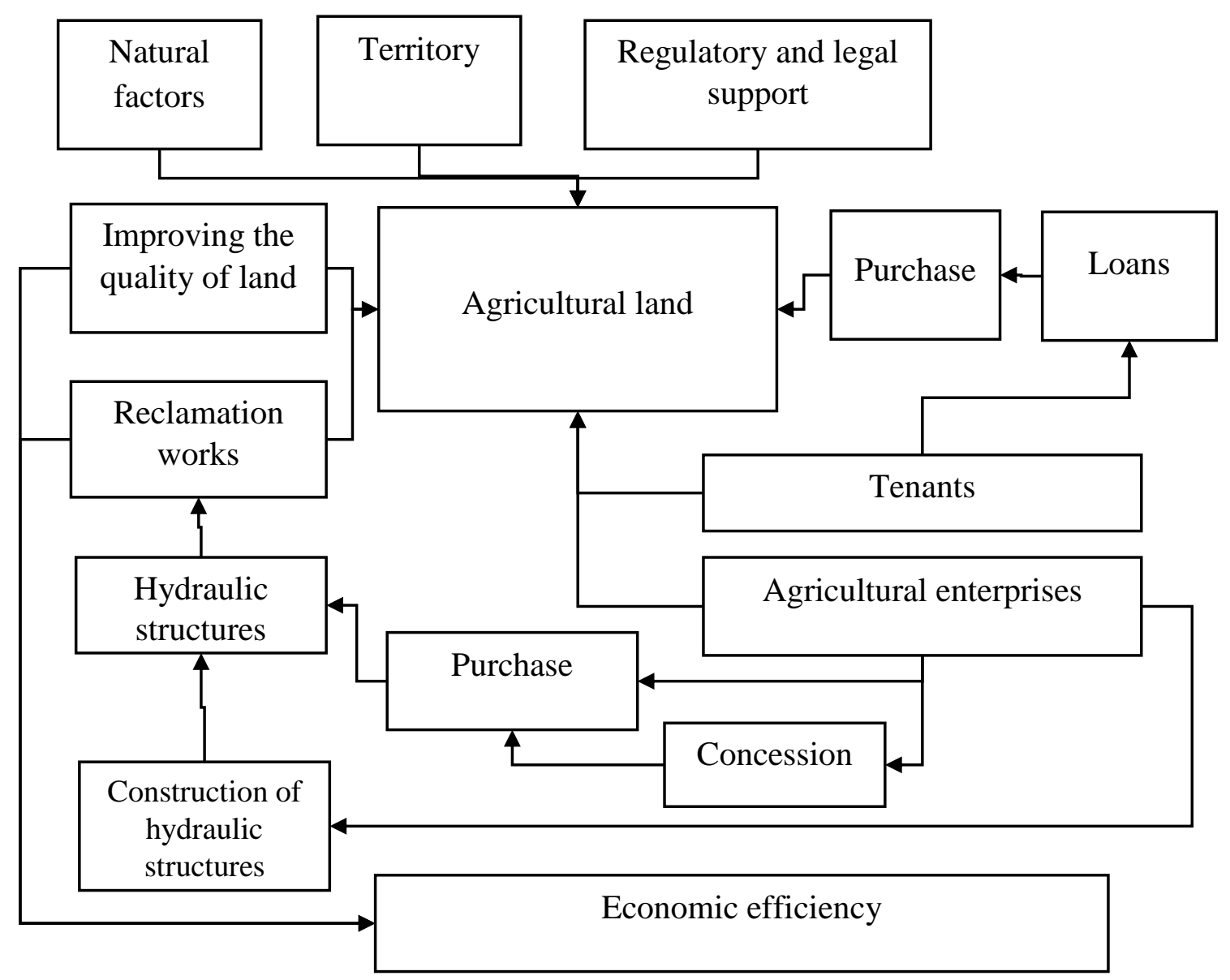

Fig. 4. Structural and logical model of overcoming drought on agricultural lands

If the trends of increasing average monthly temperatures in Ukraine in the next 10 years continue, then without land reclamation measures and additional investments to irrigate the fields, intensive agriculture will be under great threat. Not only will the area of arable land continue to decline, but the process of desertification of the Ukrainian steppe will begin. 


\section{CONCLUSIONS AND SUGGESTIONS}

In changing climatic conditions, which caused the negative impact of drought on agricultural production, there is a need to develop a reclamation complex for irrigation of agricultural land and to form effective state mechanisms of regulatory economic policy in agricultural land use.

The development of the reclamation complex should be based on the implementation of reclamation measures, in particular, the restoration and construction of new irrigation systems.

In order to implement land reclamation measures, it is necessary to ensure the effective functioning of state mechanisms of regulatory economic policy in agricultural land use, in particular:

- providing the possibility of transfer to concession to agricultural producers and the right to purchase hydraulic structures, water fund lands for the purpose of restoration, reconstruction and construction of water storage, anti-erosion and other structures for irrigation purposes;

- granting the preemptive right to purchase land plots by tenants who not only lease land, but also carry out reclamation work, making radical improvements to leased land;

- creation of conditions for crediting of land purchase operations especially under reclamation systems and for land reclamation;

- carrying out ecological and economic substantiation of land management projects and streamlining of land use systems of agricultural producers, taking into account moisture consumption in terms of crops;

- establishment of the minimum lease term for land plots where the tenant irrigates and designing measures for radical improvement of lands by land reclamation, which form inseparable improvements of lands for at least 15 years.

Thus, in drought conditions, the implementation of reclamation measures requires the adoption of the latest legal regulations and land management requirements for the use of agricultural land under reclamation projects and irrigation 
systems with the effective functioning of state mechanisms of regulatory economic policy in agricultural land use for spatial guarantees of agricultural production.

\section{REFERENCES}

Ofitsiinyi sait Derzhavnoi sluzhby Ukrainy z pytan heodezii, kartohrafiia ta kadastru [Official site of the State Service of Ukraine for Geodesy, Cartography and Cadastre]. Available at: http://land.gov.ua/info/zemelnyi-fond-ukrainy-stanom-na-1sichnia-2016-roku-ta-dynamika-ioho-zmin-u-porivnianni-z-iany ту-na-1 -sichnia2015-roku/

Poprozman N. V., Korobska A. O. (2018) Stan ta tendentsii vykorystannia zemelnykh resursiv silskohospodarskoho pryznachennia $\mathrm{v}$ konteksti natsionalnoi bezpeky derzhavy [Status and trends in the use of land resources of agricultural importance in the context of national security]. Derzhavne upravlinnia: udoskonalennia ta rozvytok. № 11. DOI: 10.32702/2307-2156-2018.11.3. Available at: http://www.dy.nayka.com.ua/?op=1\&z=1333.

Budziak O. S. (2014) Dehradatsiia ta zakhody revitalizatsii zemel Ukrainy [Degradation and measures of revitalization of lands of Ukraine]. Землеустрій, кадастр і моніторинг земель: науково-виробничий журнал. № 1-2. С. 57-64.

Stupen M. H. (2010) Kontseptualni zasady optymizatsii silskohospodarskoho zemlekorystuvannia [Conceptual principles of agricultural land use optimization]. Visnyk Lvivskoho natsionalnoho ahrarnoho universytetu: Ekonomika APK. № 17(1). C. 16-22.

Strategy for improving the management mechanism in the field of use and protection of state-owned agricultural lands and their disposal: Resolution of the Cabinet of Ministers of Ukraine (2017). Available at: http://zakon0.rada.gov.ua/laws/show/413-2017-\%D0\%BF

Kolodii P., Dub L. (2015) Teoretyko-metodolohichni osnovy ratsionalnoho vykorystannia zemelnykh resursiv [Theoretical and methodological bases of rational use of land resources]. Visnyk Lvivskoho natsionalnoho ahrarnoho universytetu: 
Ekonomika APK. № 22(2). C. 18-23. Available at: http: //nbuv.gov.ua/UJRN/Vlnau_econ_2015_22\%282\%29

Law of Ukraine "On Amendments to Certain Legislative Acts of Ukraine Concerning the Circulation of Agricultural Lands» (2020). № 20. C. 142. Available at: https://zakon.rada.gov.ua/laws/show/552-20\#Text

Yak zminiuietsia klimat $\mathrm{v}$ Ukraini [How the climate in Ukraine is changing]. Ministry of Environmental Protection and Natural Resources of Ukraine. Available at: https://mepr.gov.ua/news/35246.html.

Stan pidzemnykh vod Ukrainy [State of groundwater in Ukraine]. Shchorichnyk. DNVP «Heoinform Ukrainy». Available at: http://geoinf.kiev.ua/wp/wpcontent/uploads/2018/07/2017_sajt.pdf.

Draft Law on Amendments to the Land Code of Ukraine and Other Legislative Acts on Improving the Management System and Deregulation in the Sphere of Land $\begin{array}{llll}\text { Relations } & 2194 \text { (2019). Available }\end{array}$ http://w1.c1.rada.gov.ua/pls/zweb2/webproc4_1?pf3511=66970

Monitoring of land relations in Ukraine: 2016-2017. Statistical yearbook. URL: https://land.gov.ua/wp-content/uploads/2018/10/monitoring.pdf

Derehuliatsiia u zemelnii sferi ye neobkhidnoiu peredumovoiu peretvorennia Derzhheokadastru na servisno oriientovanu sluzhbu [Deregulation in the land sector is a necessary prerequisite for the transformation of the State Geocadastre into a service-oriented service]. Available at: https://land.gov.ua/derehuliatsiia-u-zemelniisferi-ie-neobkhidnoiu-peredumovoiu-peretvorennia-derzhheokadastru-na-servisnooriientovanu-sluzhbu/

Land decentralization-2020: moment and truth. Available at: https://land.gov.ua/zemelna-detsentralizatsiia-2020-moment-istyny/

Law of Ukraine «On National Infrastructure of Geospatial Data» (2020). № 37. C. 277. Available at: https://zakon.rada.gov.ua/laws/show/554-20\#Text

Lysenko Yu. H., Yehorov P. V., Ovechko H. S., Tymokhin V. N. (2004) Ekonomycheskaia kybernetyka: uchebn. posob. Donetsk: Yuho-Vostok. 516 c. 
Systemy krapelnoho zroshennia: novi tendentsii v ahrobiznesi [Drip irrigation systems: new trends in agribusiness]. Available at: http://apkck.gov.ua/?page=post\&id=406

\section{Г.І. Шарий, С.В. Нестеренко, В.В. Щепак}

\section{Шляхи підвищення стійкості аграрного сектору економіки}

Анотація. Розглянуто чинники, які спричиняють руйнування природних комплексів, деградації сільськогосподарських земель. Виявлено, що кризові явища державних інститутів вплинули на низьку стійкість аграрного виробництва до негативних дій природньо-кліматичного характеру. Доведена необхідність розгляду нагальної проблеми засухи, яка впливає на погіршення природних умов господарювання, a, отже, i на зниження врожайності. Вказане вимагає зміни системи агротехніки в бік розвитку меліоративного комплексу щодо зрошення сільськогосподарських земель, особливо на землях інтенсивного землеробства.

Зазначено, що неоліберальна регуляторна політика держави та лібералізація аграрних відносин зупинили розвиток інтенсивного меліорованого землеробства. Виявлено, що за останні 30 років землі 3 меліоративними системами потрапили у приватну власність фізичних осіб. Відсутність відповідальності за належне використання зрошувальних систем призвело до розриву технологічної цілісності, до руйнування їх функціональних властивостей.

Виникає потреба у формуванні системи ефективного та раціонального використання сільськогосподарських земель з урахуванням умов засухи, що дасть можливість дослідити особливості взаємодії складових системи і сформувати шляхи забезпечення балансу між ефективністю (прибутковістю) виробництва i раціональним сталим використанням земель сільськогосподарського призначення.

На основі моделювання визначено чинники впливу на організацію ефективного використання сільськогосподарських земель. Сформовано граф- 
модель системи організації ефективного та раціонального використання сільськогосподарських земель. Запропоновано структурно-логічну модель подолання засухи на сільськогосподарських землях на основі розвитку меліоративного комплексу.

В результаті проведених досліджень зроблено висновок, що перебороти вплив засухи на сільськогосподарське виробництво можливо за умови забезпечення розвитку меліоративного комплексу щодо зрошення сільськогосподарських земель та формування ефективних державних механізмів регуляторної економічної політики в сільськогосподарському землекористуванні.

Ключові слова: землі сільськогосподарського призначення, засуха, меліорація, модель, система, раціональне використання земель, стійкість аграрного виробництва.

\section{Г.И. Шарый, С.В. Нестеренко, В.В. Щепак}

\section{Пути повышения устойчивости аграрного сектора экономики}

Аннотация. Рассмотрены факторы, вызывающие разрушения природных комплексов, деградации сельскохозяйственных земель. Выявлено, что кризисные явления государственных институтов повлияли на низкую устойчивость аграрного производства к негативным воздействиям природноклиматического характера. Доказана необходимость поднятия насущной проблемы засухи, которая влияет на ухудшение природных условий хозяйствования, а, следовательно, и на снижение урожайности. Указанное требует изменения системы агротехники в сторону развития мелиоративного комплекса по орошению сельскохозяйственных земель, особенно на землях интенсивного земледелия.

Отмечено, что неолиберальная регуляторная политика государства и либерализация аграрных отношений остановили развитие интенсивного мелиорированного земледелия. Выявлено, что за последние 30 лет земли с мелиоративными системами попали в частную собственность физических лиц. 
Отсутствие ответственности за надлежащее использование оросительных систем привело к разрыву технологической целостности, к разрушению их функциональных свойств.

Возникает потребность в формировании системы эффективного и рационального использования сельскохозяйственных земель с учётом условий засухи, что даст возможность исследовать особенности взаимодействия составляющих системы и сформировать пути обеспечения баланса между эффективностью (прибыльностью) производства и рациональным постоянным использованием земель сельскохозяйственного назначения. На основе моделирования определены факторы влияния на организацию эффективного использования сельскохозяйственных земель.

На основании моделирования определены факторы влияния на организацию эффективного использования сельскохозяйственных земель. Сформирована граф-модель системы организации эффективного и рационального использования сельскохозяйственных земель. Предложена структурно-логическая модель преодоления засухи на сельскохозяйственных землях на основании развития мелиоративного комплекса.

В результате проведенных исследований сделан вывод, что преодолеть влияние засухи можно при условии обеспечения развития мелиоративного комплекса по орошению сельскохозяйственных земель и формирования эффективных государственных механизмов регуляторной экономической политики в сельскохозяйственном землепользовании.

Ключевые слова: земли сельскохозяйственного назначения, засуха, мелиорация, модель, система, рациональное использование земель, устойчивость аграрного производства. 